\title{
EFFECTS OF WATER QUALITY ON PHYTOPLANKTON BIOMASS IN BALU RIVER, DHAKA, BANGLADESH
}

\author{
Bhuiyan, M. A. H., M. R. Islam, S. A. M. S. Islam ${ }^{1}$, A. Kowser, M. Mohid, S. A. Kakoly and M. \\ Khondker \\ Department of Botany, University of Dhaka, Dhaka-1000, Bangladesh; ${ }^{1}$ Plant Biotechnology and \\ Genetic Engineering Division, Institute of Food and Radiation Biology (IFRB), AERE, Bangladesh \\ Atomic Energy Commission, Savar, Dhaka-1349, Bangladesh
}

\begin{abstract}
The Balu River is a peripheral river of Dhaka Metropolis and like other rivers its water quality is also highly vulnerable towards pollution. In the present study, effects of water quality parameters on the phytoplankton biomass have been studied for six climatic seasons of the year. The results obtained were compared with two other rivers of Dhaka Metropolis namely, Buriganga and Turag. Balu River showed water quality characters almost comparable with two other rivers. The phytoplankton biomass as chlorophyll $a$ (chla) was found to be correlated directly with air and water temperature and alkalinity of the water. However, a weak positive correlation was obtained between chl-a and Secchi depth and free $\mathrm{CO}_{2}$ concentration. Nitrate nitrogen showed weak negative correlation with chl-a and phaeopigment and phytoplankton total density. High fluctuation was observed in the concentration of DO $(0.20-4.50 \mathrm{mg} / \mathrm{l})$ and free $\mathrm{CO}_{2}(0.06-2.90 \mathrm{mg} / \mathrm{l})$ throughout the seasons. Soluble reactive phosphorus ranged from 30 - $1248 \mu \mathrm{g} / \mathrm{l}$ and chl-a ranged from 6.77 $32.60 \mu \mathrm{g} / \mathrm{l}$. Phytoplankton density ranged $1178-7409 \times 10^{3}$ ind./l over the study year. Water color ranged from light blue to dark black. The depth of visibility as Secchi depth varied from $15.24-81.28 \mathrm{~cm}$ whilst the water depth of the studied station Paschim Gaon of Balu River ranged from 4.57 - $7.92 \mathrm{~m}$. Air and water temperature ranged from $25.4-36.5^{\circ} \mathrm{C}$ and $23.4-32.3^{\circ} \mathrm{C}$, respectively.
\end{abstract}

Key words: Phytoplankton; Balu River; Water quality; Biomass.

\section{INTRODUCTION}

Activity of rivers is legendary in carrying symbols of historical past, commerce, culture and socioeconomic activities of landscape and people. Dhaka Metropolis has a few peripheral rivers namely, Buriganga, Sitalakhsya, Turag and Balu. Despite their tremendous contribution to the city dwellers, they are severely affected from both of their physical set up and water quality. It is now well understood that, this condition could no longer be tolerated in order to safeguard the history, culture and socio-economic activities of the citizens of Dhaka Metropolis. Several strong measures have already been taken to protect the peripheral rivers of Dhaka Metropolis. Starting from 1972 until recently chronological water quality information of the River Buriganga near Dhaka is available (Islam et al. 1974, Islam and Zaman 1975, Ahmed 1993, Ferdous et al. 2012, Raknuzzaman 2006, Zerin et al. 2017, Bhuiyan and Khondker 2018). During this period, because of severe eutrophication and water pollution the river Buriganga showed an increasing trend in chl-a with a declining biodiversity of pelagic plankton. Khondker and Abed (2013) published the physicochemical and biological water quality data of the River Turag. In this study a comparison with some earlier information revealed that within a span of one decade the soluble reactive phosphorus raised 3 fold and nitrate nitrogen raised 32 fold in the river showing a clear sign of strongest eutrophication. Though the river Buriganga and Turag have been investigated limnologically in the past, similar information on the river Balu is meager. The present investigation has therefore been undertaken to study some selected water quality parameters at Paschim Gaon Station of Balu River. 


\section{MATERIAL AND METHODS}

The present investigation was carried out at a point situated in the main course of the Balu River. Balu River originates from Paruli River and Sutia River in Gazipur District and passes through a number of low lying areas and Beel Belai of Dhaka and finally meets the River Sitalakhsya at Demra. So, actually it is a small tributary of Sitalakhsya River and $44 \mathrm{~km}$ in length. Balu River has got also indirect connection with the Turag River via Tongi Khal. During flooding season, Balu River carries flood water from Sitalakhsya and Turag (Chowdhury 2012). The geographical coordinates of the location of the river has been provided in Table 1 .

For collecting samples in the Balu River, one permanent perennial station named Paschim Gaon has been fixed (Fig. 1). The station was visited in the years of 2017 and 2018; and at least once in each of the 6 climatic seasons of Bangladesh as stated in 'Geography of Bangladesh' (Rashid 1998). Detail information on methodologies applied for collecting samples of water and plankton, instruments used for carrying out in situ for laboratory measurements, quantification of plankton, etc. have been presented in Table 1. To preceed quantification of phytoplankton, at first qualitative analysis was done with the help of a Zeiss Phase Contrast Microscope with photographic attachment (Carl Zeiss Microscopy GmbH, Carl-Zeiss-Promenade 10, 07745 Jena, Germany, Model-Axio. LabA1). Phytoplankton taxa appeared in the samples collected from the river were identified with the help of national and international publications (Ahmed et al. 2008, Ling and Tyler 2000, Dillard 1989, Prescott 1982). The quantification was carried out at 400x under a Nikon Students Microscope, Japan. The total density of phytoplankton was then calculated to individuals per liter of the river water. The effect of various water quality parameters on the phytoplankton biomass as chl-a was determined by Pearson's Comelation Analysis.

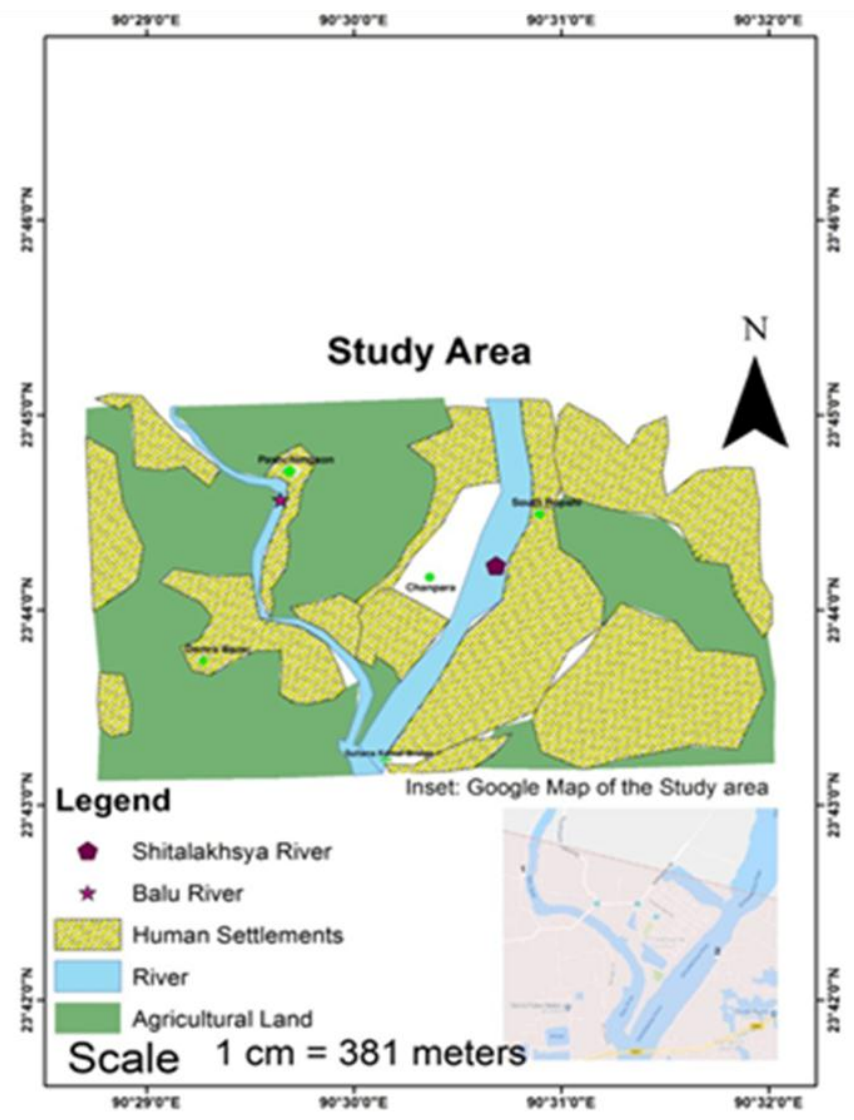

Fig. 1. Map of Balu River near Dhaka Metropolis showing the sampling station at Paschim Gaon. 
Table 1. Presenting information on study site, sample collection, time and period, sample transport, methods of analyses and units of measurement used.

\begin{tabular}{|c|c|}
\hline Name (official) of the river studied & Balu River, Dhaka \\
\hline Name of the sampling station & Paschim Gaon \\
\hline Latitude & 23.742840 \\
\hline Longitude & 90.494121 \\
\hline Sample collecting time & in between 10:00 AM and 12:30 PM \\
\hline $\begin{array}{l}\text { Time required to bring the sample to the } \\
\text { laboratory }\end{array}$ & 2 hours \\
\hline $\begin{array}{l}\text { Completing time of analyses of all } \\
\text { physicochemical parameters }\end{array}$ & Within 48 hours of bringing the sample in the laboratory. \\
\hline $\begin{array}{l}\text { Periods (date of collection with observed water } \\
\text { color) }\end{array}$ & $\begin{array}{l}\text { Summer ( } 26 \text { May 2017, Black), Rainy ( } 8 \text { August 2017, Slightly black), } \\
\text { Autumn (13 October 2017, Slightly blue) Late Autumn ( } 5 \text { December } \\
\text { 2017, slightly black) and Winter ( } 12 \text { February 2018, Dark black), } \\
\text { Spring ( } 31 \text { March 2018, Black) }\end{array}$ \\
\hline \multicolumn{2}{|l|}{ Methodology, equipments and units used } \\
\hline Water depth $(\mathrm{Z})$ : & In meter $(\mathrm{m})$, using a graduated rope carrying a weight at the end \\
\hline Secchi depth (Zs): & In meter $(\mathrm{m})$, Secchi disc (Welsch 1948) \\
\hline Air temperature (Air temp.): & In degree Celsius $\left({ }^{\circ} \mathrm{C}\right)$, in situ, using mercury thermometer \\
\hline Water temperature (Wat. Temp): & $\begin{array}{l}\text { In degree Celsius }\left({ }^{\circ} \mathrm{C}\right) \text {, in situ, using mercury thermometer housed in a } \\
5 \text { liter capacity Schindler's water sampler (Wetzel and Likens 2000) }\end{array}$ \\
\hline Total dissolved solids (TDS): & $\begin{array}{l}\text { Milligram per liter (mg), measured in situ, using Hanna Multi } \\
\text { Instruments Code-HI9813-6, S/N-D0108196, Romania }\end{array}$ \\
\hline Electrical conductivity (cond.): & $\begin{array}{l}\text { Micro-Siemens per centimeter }(\mu \mathrm{S} / \mathrm{cm}) \text {, same as above } \mathrm{pH} \text { : same as } \\
\text { above }\end{array}$ \\
\hline Dissolved oxygen (DO): & $\begin{array}{l}\text { Milligram per liter (mg/l), Winkler's method, sample fixed in the field } \\
\text { (Wetzel and Likens } 2000 \text { ) }\end{array}$ \\
\hline Free carbon dioxide $\left(\mathrm{CO}_{2}\right)$ : & Milligram per liter (mg/l), Titration (Welsch 1948) \\
\hline Alkalinity (Alkal.): & Milliequivalent per liter (meq/l), Titration (Mackereth et al. 1978) \\
\hline Soluble reactive phosphorus (SRP): & $\begin{array}{l}\text { Microgram per liter }(\mu \mathrm{g} / \mathrm{l}), \text { Spectrophotometric } \\
\text { Riley1962), Schimadzu, Japan }\end{array}$ \\
\hline Soluble reactive silicate (SRS): & Milligram per liter (mg/l), same as above (Wetzel and Likens 2000 ) \\
\hline Nitrate nitrogen $\left(\mathrm{NO}_{3}-\mathrm{N}\right)$ : & $\begin{array}{l}\text { Milligram per liter }(\mathrm{mg} / \mathrm{l}) \text {, same as above (Müller and Wiedemann } \\
1955)\end{array}$ \\
\hline Chlorophyll a (Chl-a): & $\begin{array}{l}\text { Microgram per liter }(\mu \mathrm{g} / \mathrm{l}) \text {, Spectrophotometric (Marker et al. 1980), } \\
\text { Schimadzu, Japan }\end{array}$ \\
\hline Phaeopigment (Phaeo.): & Microgram per liter $(\mu \mathrm{g} / \mathrm{l})$, same as above \\
\hline Phytoplankton density (PD): & $\begin{array}{l}\text { Individuals per liter (ind./l), Helber Microplankton Counting Chamber, } \\
\text { Thoma ruling, Hawksley Technology, UK (Wetzel and Likens } 2000 \text { ) }\end{array}$ \\
\hline
\end{tabular}

Data on relative humidity and rainfall, measured in nearest meteorological station of the Balu River were collected from the Meteorological Department, Agargaon, and Dhaka.

\section{RESULTS AND DISCUSSION}

Inclusive two collected climatological parameters (humidity and rainfall), altogether 20 parameters were analyzed and recorded in the present investigation. Each record of data sets in a particular season has been plotted in Fig. 2a-f and 3a-c. Fig. 2a shows the fluctuation of rainfall and percentage of relative humidity over the period of investigation. Highest rainfall $(450 \mathrm{~mm})$ was recorded in August while the least in February. Humidity also ranged in the same pattern (Fig. 2a). Relationship between air and water temperature followed the similar pattern. Their highest was obtained in October and lowest in February. Air temperature was always higher compared to the corresponding values of water temperature $(2 \mathrm{~b})$. Water depth of the sampling station had been monitored which ranged between 4.50 
and $7.92 \mathrm{~m}$. Highest water depth at the sampling station (Paschim Gaon) was recorded in August, December and March. The river water was however remained more transparent during the month of August $(\mathrm{Zs}=0.80 \mathrm{~m})$. The lowest depth of visibility was obtained in February $(\mathrm{Zs}=0.15 \mathrm{~m})$.

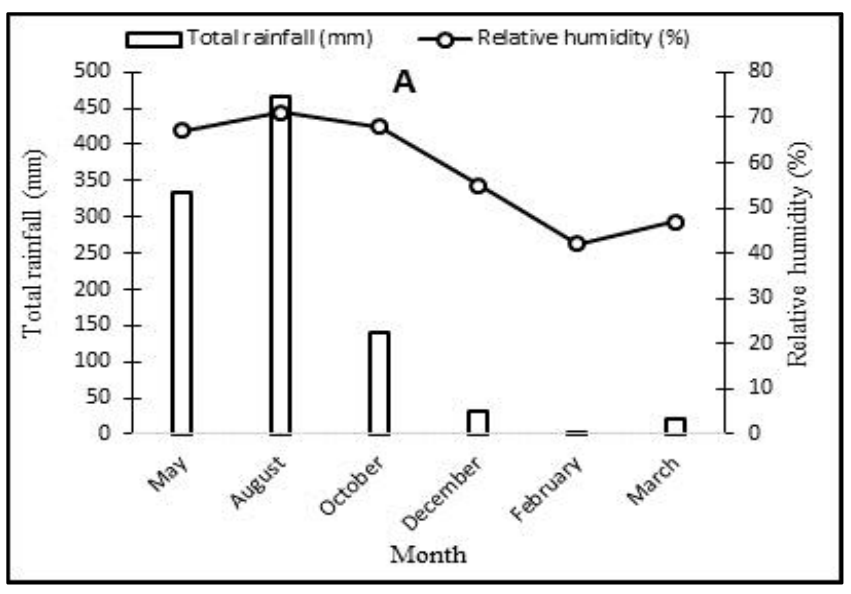

a

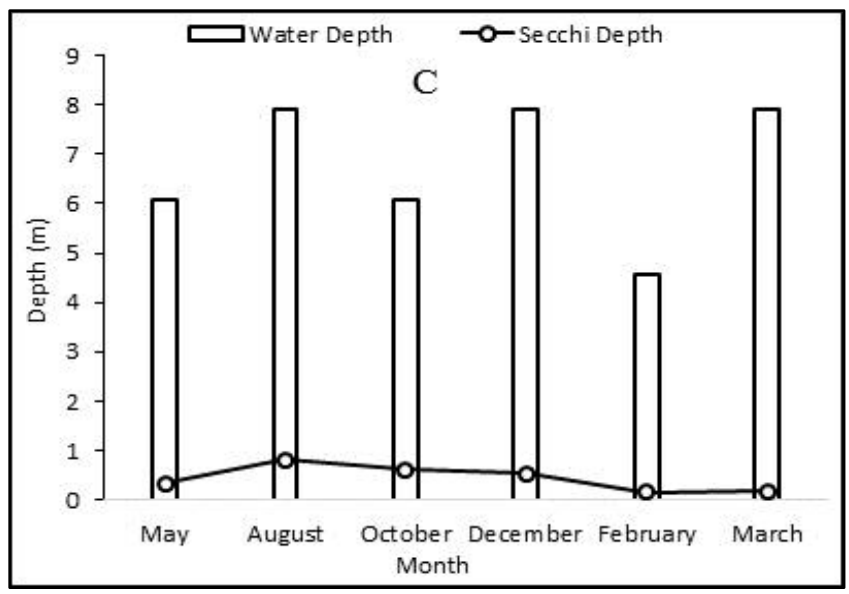

c

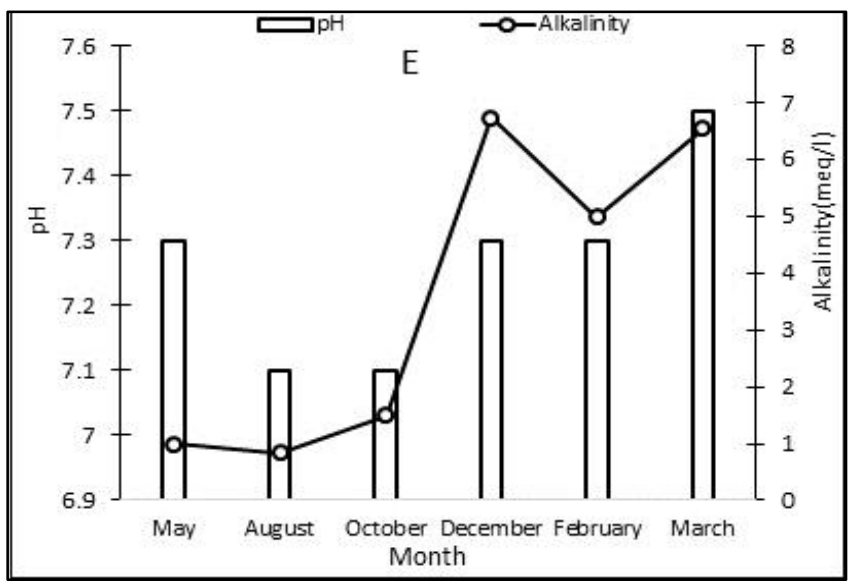

e

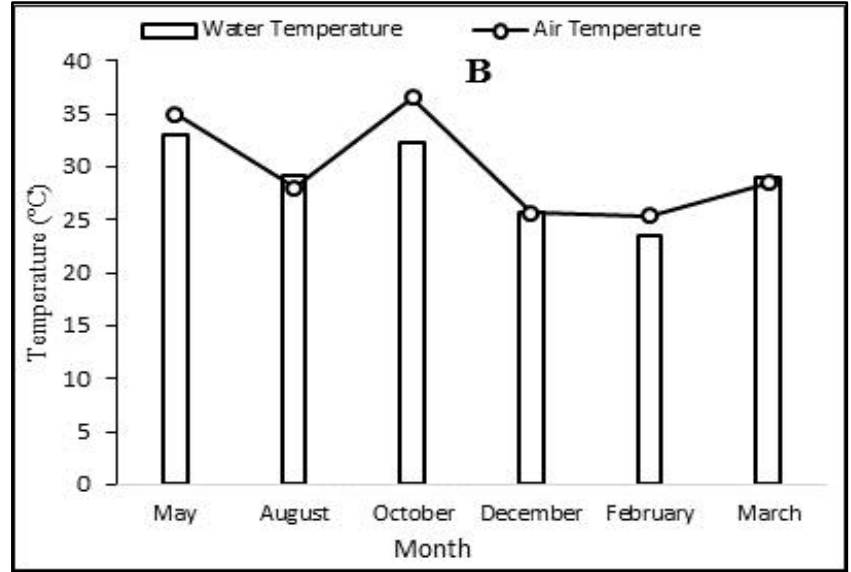

b

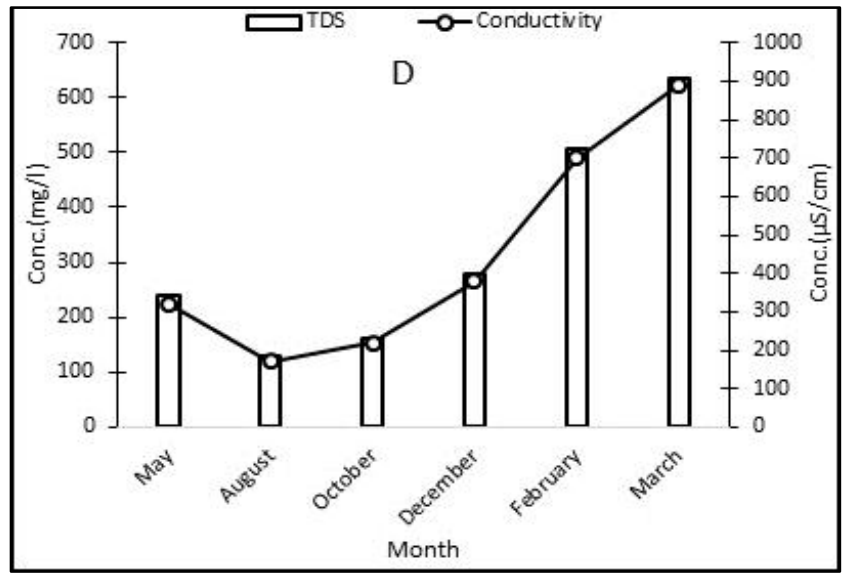

d

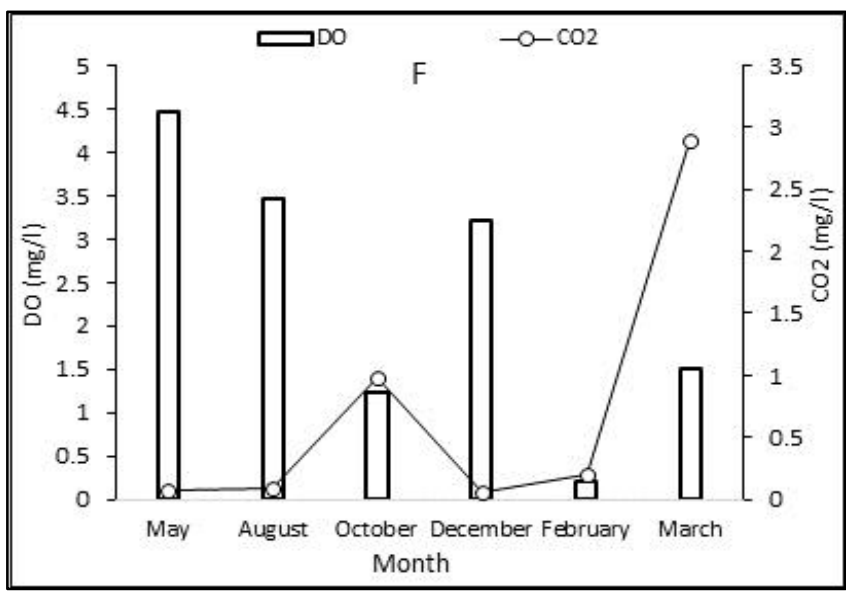

f

Fig. 2. Seasonality of various climatological and physicochemical parameters at Paschim Gaon station of Balu River: a. rainfall and humidity; b. air and water temperature; c. water depth and Secchi depth; d. Total dissolved solids (TDS) and electrical conductivity; e. $\mathrm{pH}$ and alkalinity; and f. dissolved oxygen (DO) and free carbon dioxide $\left(\mathrm{CO}_{2}\right)$. 
A direct relationship has been observed in the load of TDS (total dissolved solids) and electrical conductivity of water (Fig. 2d). Both the parameters rose during the lean months of the river. The $\mathrm{pH}$ of water ranged from 7.1-7.5, being the highest in the lean month March. The alkalinity varied from 1.00$6.75 \mathrm{meq} / \mathrm{l}$. The highest value is exceptionally high for any water body which did occur during the dry period of the river. Of the biogenic gases, the concentration of DO ranged between 0.2 and $4.47 \mathrm{mg} / \mathrm{l}$ while free $\mathrm{CO}_{2}$ ranged from 0.07 to $2.90 \mathrm{mg} / \mathrm{l}$. Fig. 3a shows the fluctuation of SRP and phytoplankton biomass as chl-a in the Paschim Gaon Station of Balu River. The highest biomass of phytoplankton $(32.6 \mu \mathrm{g} / \mathrm{l})$ occurred in October during which the SRP content $(146.5 \mu \mathrm{g} / \mathrm{l})$ elevated a little from its previous record in August $(55.45 \mu \mathrm{g} / \mathrm{l})$. The maximum value of SRP recorded for the studied station of the Balu River was $1247.62 \mu \mathrm{g} / \mathrm{l}$.
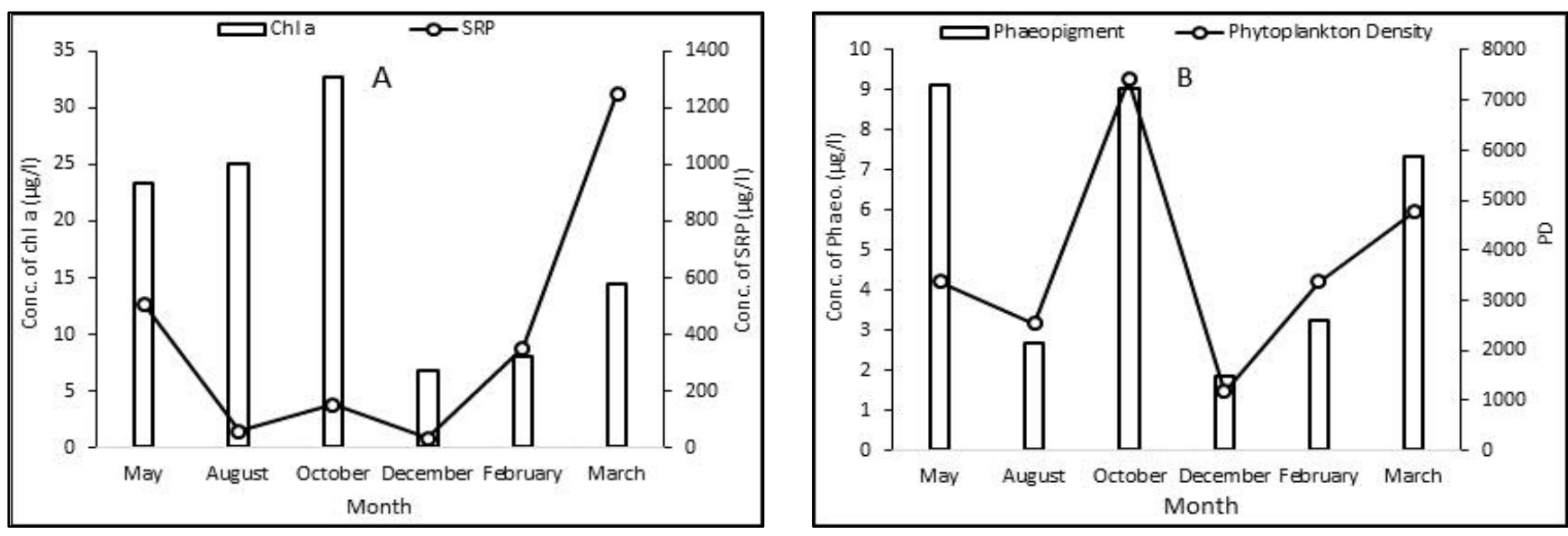

$\mathbf{a}$

b

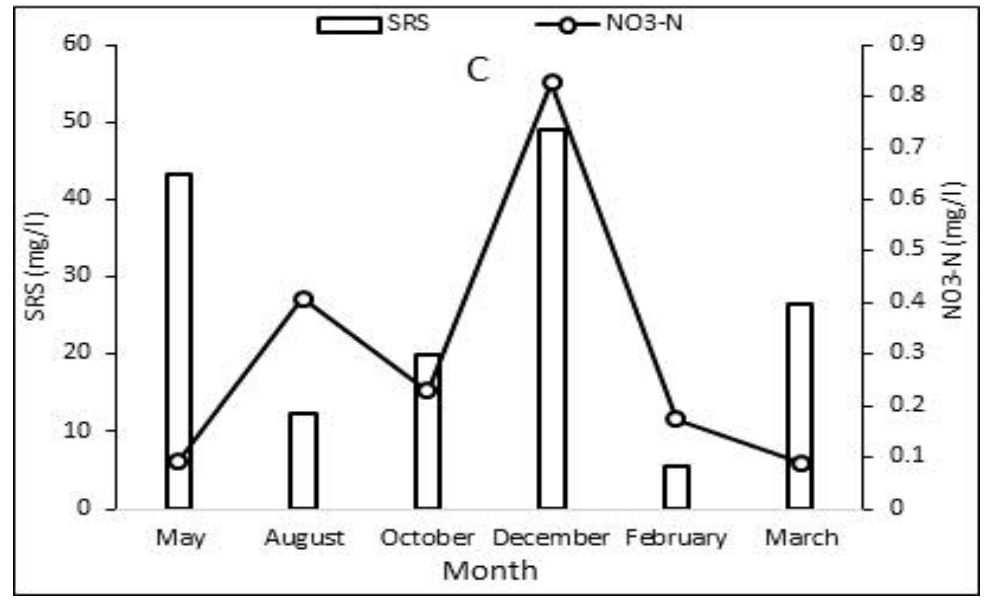

c

Fig. 3. Seasonality of various physicochemical and biological parameters at Paschim Gaon Station of Balu River: a. chlorophyll $a$ and soluble reactive phosphorus (SRP); b. phaeopigment and phytoplankton density (PD); and c. soluble reactive silicate (SRS) and nitrate nitrogen $\left(\mathrm{NO}_{3}-\mathrm{N}\right)$.

The concentration of the degraded product (phaeopigment) of phytoplankton biomass (chl-a) corresponds the highest density of the latter. Both the phytoplankton density (7409 ind./l) and the concentration of phaeopigment $(9.04 \mu \mathrm{g} / \mathrm{l})$ was higher in October (Fig. 3c), but the trend was little different in May when the conc. of phaeopigment was found high $(9.13 \mu \mathrm{g} / \mathrm{l})$ with a corresponding low density of phytoplankton (3372 ind/l). The concentration of SRS in the studied station of Balu River ranged from 5.65-48.90 mg/l. High concentration was recorded in December whilst its lower value was 
obtained in February (Fig. 3c). Highest nitrate-nitrogen concentration did overlap with the SRS value in the same month.

In the investigation, air and water temperature were interdependent with each other as it has been revealed from the correlation analysis (significant at 0.05 level). Significant negative correlation was found among $\mathrm{Zs}, \mathrm{TDS}, \mathrm{pH}$ and conductivity (significant at 0.05 level). SRP showed positive correlation with $\mathrm{pH}$ and free $\mathrm{CO}_{2}$ (significant at 0.05 level). To find the effect of different water quality parameters on the phytoplankton derived factors data from the correlation matrix has been synthesized and presented in Table 3. From Table 3 it has been seen that temperature (both air and water) showed a positive correlation with all the phytoplankton derived factors namely, chl-a, phaeopigment and total plankton density (PD). But the relationship was significant only in cases of chl-a and phaeopigment (significant at 0.05 level). Nitrate-nitrogen showed negative correlation with all the phytoplankton parameters but those were weak (Table 3). Similar relationship was also shown by alkalinity with the phytoplankton parameters but showed significant negative relationship with chl-a (significant at 0.05 level). Water transparency (Zs) and DO showed weak positive correlation with chl-a and $\mathrm{CO}_{2}$ showed the same interaction with the phaeopigment.

Table 3. Showing the effects of key water quality parameters on the biomass, degraded product and the standing crop of phytoplankton at Paschim Gaon Station of Balu River (synthesized from Pearsons correlation matrix).

\begin{tabular}{lccc}
\hline Parameter & Chl-a & Phaeopigment & Phytoplankton Density \\
\hline Air temp. & $0.850^{*}$ & $0.888^{*}$ & 0.704 \\
Wat. temp. & $0.860^{*}$ & $0.816^{*}$ & 0.529 \\
$\mathrm{Zs}$ & 0.543 & -0.235 & -0.068 \\
$\mathrm{DO}$ & 0.208 & 0.029 & -0.493 \\
$\mathrm{CO}_{2}$ & 0.013 & 0.419 & 0.505 \\
$\mathrm{Alkal}$ & $-0.858^{*}$ & -0.394 & -0.299 \\
$\mathrm{SRP}$ & -0.165 & 0.457 & 0.265 \\
$\mathrm{NO}_{3}-\mathrm{N}$ & -0.364 & -0.711 & -0.609 \\
\hline
\end{tabular}

The range of air temperature recorded in the present investigation $\left(25.4-36.5^{\circ} \mathrm{C}\right)$ is comparable with the studies carried out by Islam et al. (1974) in the river Buriganga $\left(29.0-34.0^{\circ} \mathrm{C}\right)$. As in the present investigation, a direct relationship between air and water temperature was also recorded for the River Buriganga (Islam et al. 1974). The water temperature range $\left(23.4-33.0^{\circ} \mathrm{C}\right)$ recorded for Balu River is almost similar to those recorded for Buriganga (Islam et al. 1974, Zerin et al. 2017, Islam and Moniruzzaman 2011, Sarker et al. 2015). Although, the lower range of water temperature in all these studies varied within $20-26^{\circ} \mathrm{C}$, the highest $\left(30.0-33.0^{\circ} \mathrm{C}\right)$ were almost same for the present study. The recorded range of water temperature is also similar for Turag River (Khondker and Abed 2013). When the recorded data on relative humidity and rainfall collected for the present investigation is compared with those for Buriganga in between 1972 and 1973, a lower range could be observed for both of these climatological parameters. The relative humidity recorded by Islam et al. (1974) for the river Buriganga was 61.0-88.6\% whilst for Balu River the value ranged from $42-71 \%$. The ranges of recorded rainfall for Buriganga (Islam et al. 1974) and for Balu River (present investigation) were 1.02 - $645.67 \mathrm{~mm}$ and 1.1 - $465 \mathrm{~mm}$, respectively.

Balu River essentially is a drainage river and acting as a tributary of Sitalakhsya River (Chowdhury 2012), as a result there is a little impact of rainfall on the hydrological regime of it. Highest water depth $7.92 \mathrm{~m}$ occurred at highest rainfall $465 \mathrm{~mm}$ but at other times i.e., in December and March the river had same water depth but there was very little rainfall. It means the hydrological regime of the river is dependent on other sources rather than rainfall. Industrial discharge could be one reason of it. The intensity of industrial discharge seems to be very high since the water color remained mostly light to 
heavy dark. This finding is also supported by Chowdhury (2012). The range of the depth of visibility (Zs) of Balu River was $15.24-81.58 \mathrm{~cm}$. Saifullah et al. (2012) recorded a range of Zs from 18.00 $27.00 \mathrm{~cm}$ for the river Buriganga and Khondker and Abed (2013) recorded a range of $26.5-35.0 \mathrm{~cm}$ for Turag. From this comparison it could be said that the visibility of Balu River water is little better.

Table 4. Comparison of water quality parameters among some peripheral rivers of Dhaka Metropolis and the River Gomti of Cumilla.

\begin{tabular}{|c|c|c|c|c|c|c|}
\hline $\begin{array}{l}\text { Water quality } \\
\text { parameters }^{1}\end{array}$ & $\begin{array}{c}\text { Balu River } \\
\text { (Present } \\
\text { study) }\end{array}$ & $\begin{array}{c}\text { Buriganga } \\
\text { (Zerin et al. } \\
\text { 2017) }\end{array}$ & $\begin{array}{c}\text { Buriganga } \\
\text { (Islam and } \\
\text { Moniruzzaman } \\
\text { 2011) }\end{array}$ & $\begin{array}{c}\text { Buriganga } \\
\text { (Bhuiyan and } \\
\text { Khondker } \\
\text { 2018) }^{2}\end{array}$ & $\begin{array}{c}\text { Turag } \\
\text { (Khondker } \\
\text { and Abed } \\
\text { 2013) }\end{array}$ & $\begin{array}{c}\text { Gomti } \\
\text { (Bhuiyan and } \\
\text { Khondker } \\
\text { 2018) }\end{array}$ \\
\hline Air temp. $\left({ }^{\circ} \mathrm{C}\right)$ & $25.4-36.5$ & - & $15.0-35.0$ & $29.0-36.5$ & - & $28.0-36.0$ \\
\hline Wat. Temp. $\left({ }^{\circ} \mathrm{C}\right)$ & $23.4-32.3$ & $20.0-30.0$ & $20.0-33.0$ & $27.0-35.5$ & $20.8-30.5$ & $26.0-34.0$ \\
\hline $\mathrm{Z}(\mathrm{m})$ & $4.57-7.92$ & - & - & $8.00-11.80$ & - & $5.00-7.50$ \\
\hline Zs (cm) & $15.24-81.28$ & $17.00-95.00$ & $17.00-60.00$ & $49.00-62.00$ & $26.50-35.00$ & $19.00-38.00$ \\
\hline TDS (mg/l) & $128-634$ & - & $55-394$ & $113-205$ & - & 44-120 \\
\hline Cond. $(\mu \mathrm{S} / \mathrm{cm})$ & $17-890$ & $110-640$ & $115-915$ & $635-750$ & $175-608$ & $250-350$ \\
\hline $\mathrm{pH}$ & $7.1-7.5$ & $6.8-8.1$ & $6.7-6.9$ & $7.9-8.8$ & $7.1-7.5$ & $7.5-7.9$ \\
\hline $\mathrm{DO}(\mathrm{mg} / \mathrm{l})$ & $0.20-4.50$ & $0.30-12.80$ & $<0.02-9.40$ & $2.90-4.60$ & $0.84-8.97$ & $7.52-8.20$ \\
\hline Free $\mathrm{CO}_{2}(\mathrm{mg} / \mathrm{l})$ & $0.06-2.90$ & - & - & $7.22-10.00$ & - & $4.66-6.25$ \\
\hline Alkal. (meq/l) & $0.84-6.55$ & $1.00-4.90$ & $1.00-6.60$ & $0.80-2.50$ & $1.17-3.67$ & $0 .-1.72$ \\
\hline $\operatorname{SRP}(\mu \mathrm{g} / \mathrm{l})$ & $30-1248$ & $38-508$ & $34-1584$ & $410-610$ & $42-405$ & $130-270$ \\
\hline SRS (mg/l & $5.65-43.35$ & $3.00-38.00$ & $4.00-76.00$ & $10.50-60.66$ & $7.81-32.64$ & $17.00-40.00$ \\
\hline $\mathrm{NO}_{3}-\mathrm{N}(\mathrm{mg} / \mathrm{l})$ & $0.089-0.83$ & $0.40-10.90$ & $0-0.30$ & $0.65-1.15$ & $0.07-0.53$ & $0.11-0.85$ \\
\hline Chl-a $(\mu \mathrm{g} / \mathrm{l})$ & $6.77-32.60$ & $2.00-142.00$ & $2.00-160.00$ & - & $2.35-87.29$ & - \\
\hline Phaeo. $(\mu \mathrm{g} / \mathrm{l})$ & $1.85-9.13$ & - & - & - & $3.36-20.68$ & - \\
\hline $\mathrm{PD}\left(\times 10^{3} \mathrm{ind} / \mathrm{l}\right)$ & $1178-7409$ & $36-133152$ & $1-197$ & - & $92-451$ & - \\
\hline
\end{tabular}

${ }^{1}$ Full meaning of the abbreviations used in this column could be obtained from Table 1 of this paper.

${ }^{2}$ Six months study (May to October, 2011).

Water quality data available so far from some peripheral rivers of Dhaka Metropolis and one river from Cumilla district has been compared with the data of Balu River and presented in Table 4. The data seems to be quite consistent for river ecosystems of Bangladesh. Though the data set is not fully annual for Gomti River, yet it represents characteristic features of non-urban river. For example TDS, electrical conductivity, alkalinity and SRP content of Gomti River is relatively low (Table 4). The transparency value (Zs) of Gomti is similar to Turag. The Gomti River possesses a low transparency because it is originated from the nearby hillocks, which causes a high load of silt materials in its water. Turag has got also a low transparency because the studied station (near Mirpur Bridge at Gabtali) was too much affected by human activities which caused a loading of high silt material in its water. The maximum value of transparency of Balu $(81 \mathrm{~cm})$ is comparable with that of Buriganga $(91 \mathrm{~cm})$. The maximum value of SRP for Balu and Buriganga is nearly 3 times higher than the value recorded for Turag River. This feature suggests that the phosphorus loading from the external sources are relatively higher in these two rivers.

Since the biomass and composition of potamoplankton (running water plankton) in rivers is a good indicator of water quality and which in turn are affected by myriads of factors, it is customary to have an analysis on this issue. Data extracted from the Pearson's correlation matrix relevant to phytoplankton biomass and other related parameters have been produced in Table 3 . The result indicates that air and water temperature and alkalinity correlated significantly with the phytoplankton biomass of the pelagic of the Balu River. The relationship between alkalinity and chl-a was also significant in Turag River (Khondker and Abed 2013). Khondker and Kabir (1995) found significant positive correlation between 
phytoplankton biomass as chl-a and water temperature and alkalinity in a mesotrophic pond water of Dhaka Metropolis. Free $\mathrm{CO}_{2}$ showed a weak positive correlation with phaeopigment and phytoplankton density (PD). $\mathrm{NO}_{3}-\mathrm{N}$ showed weak but a negative correlation with chl-a, phaeopigment and PD (Table 3). Positive relationship between free $\mathrm{CO}_{2}$ and alkalinity and phytoplankton parameters shows a kind of dependency of the latter on the former factors, since the former factors act as a reserve of molecular and bound carbon dioxide which are essential raw materials for photosynthesis.

Balu River is a drainage channel of running water ecosystem near Dhaka Metropolis, holding characteristic features of urban rivers. Its water quality is comparable with two other important rivers namely, Buriganga and Turag with few exceptions. It differs from the river Buriganga having high TDS value and from Turag having an improved transparency and phytoplankton density. The trend of annual fluctuation of DO for contaminated urban section of rivers (i.e., from a lower value closer to anoxia to a moderate or high value) is quite evident in case of Balu River (Table 4). Slight bluish to dark black water color, high values of TDS and electrical conductivity, alkalinity and SRP and a relatively low chla suggests intensive industrial discharge and domestic and agricultural contamination of the river water.

\section{ACKHONWLEDGEMENTS}

The authors gratefully acknowledge the Centre for Advanced Studies and Research in Biological Sciences, University of Dhaka for the financial support to carry out this research work.

\section{REFERENCES}

Ahmed, M. F. 1993. The effect of bio-degradable organic pollutants on aquatic ecosystem of the River Buriganga. In: M. M. Tilzer and M. Khondker (eds.). Hypertrophic and Polluted Freshwater Ecosystems: Ecological bases for water Resources Management. Prof. Int. Symp. Limnol., Dept. of Botany, University of Dhaka, Bangladesh., pp. 97-108.

Ahmed, Z. U., Z. N. T. Begum, M. A. Hassan, M. Khondker, S. M. H. Kabir, M. Ahmad, A. T. A. Ahmed, A. K. A. Rahman and E. U. Haque (eds.). 2008. Encyclopedia of Flora and Fauna of Bangladesh. Vol. 3. Algae. Chlorophyta (Aphanochaetaceae-Zynemataceae). Asiatic Society of Bangladesh, Dhaka. 812 pp.

Bhuiyan, M. A. H and M. Khondker. 2018. Water quality and potamoplankton of the river Buriganga and Gomti: A comparison. Dhaka Univ. J. Biol. Sci. 27(2): 191-200.

Chowdhury, S. Q. 2012. Balu River. In: S. Islam and A. A. Jamal. (eds). Banglapedia: National Encyclopedia of Bangladesh. 2nd ed. Asiatic Society of Bangladesh, Dhaka.

Dillard, G. E. 1989. Freshwater algae of the Southeastern United States. Part 1. Chlorophyceae: Volvocales, Tetrasporales and Chlorococcales. J. Cramer, Berlin, Bangladesh. 202 pp.

Ferdous, Z., S. Akter, M. Hasan, R. A. Begum and R. M. Shahajahan. 2012. Phytoplankton diversity and abundance in relation to pollution levels in the Hazaribagh tannery effluent sewage water of the river Buriganga. Bangladesh J. Zool. 40(1): 121-128.

Islam A. K. M. N., A. K. Y Haroon and K. M. Zaman. 1974. Limnological studies of the river Buriganga. 1. Physical and chemical aspects. Dacca Univ. Stud. Pt. B. 22(2): 99-111.

Islam, A. K. M. N. and K. Moniruzzaman. 2011. Limnology of one of the worst affected rivers in Bangladesh: Phytoplankton diversity, its seasonality and pollution status. Lap. Lambert Acad. Publ. $180 \mathrm{pp}$. 
Islam, A. K. M. N. and K. M. Zaman. 1975. Limnological studies of the river Buriganga. III. Biological aspect. J. Asiatic Soc. Bangladesh (Sci.). 1(1): 45-65.

Khondker, M. and M. A. Kabir. 1995. Phytoplankton primary production in a mesotrophic pond in subtropical climate. Hydrobiologia. 304: 39-47.

Khondker, M and G. Abed. 2013. Seasonality of phytoplankton productivity of the River Turag of Dhaka in relation to its water quality. Bangladesh J. Bot. 42(2): 287-294.

Ling, H. U. and P. A. Tyler. 2000. Australian Freshwater Algae (exclusive of diatoms). Bibl. Phycol. Bd. 105.J. Cramer, Berlin. 643 pp.

Mackereth, F. J. H., J. Heren and J. F. Talling. 1978. Water analysis. Some revised methods for Limnologists. Freshwater Biol. Assoc. Sci. 36: 119.

Marker, A. F. H, E. A. Nusch, H. Rai and B. Riemann. 1980. The measurement of photosynthetic pigments in freshwaters and standardization of methods: conclusions and recommendations. Arch. Hydrobio. Beih. Ergebn. Limnol. 14: 91-106.

Muller, R and F. Wiedemann. 1955. Die Bestimmung des Nitrates in Wasser. Jahrbuch fur Wasserchemie und Wasserreinigungtech. 12: 247-271.

Murphy, J. and R. P. Riley. 1962. A modified simple solution method for the determination of phosphate in natural water. Anal. Chim. Acta. 27: 31-36.

Prescott, G. W. 1982 (Reprinted). Algae of the Western Great Lakes area. Otto Koeltz Science Publ. Koenigstein, Germany. 977 pp.

Raknuzzaman. M. 2006. Comparative studies on physicochemical variables and zooplankton abundances in polluted waters of Buriganga river. The CDR J. 1(2): 99-106.

Rashid, H. E. R 1991. Geography of Bangladesh. 2nd ed. Univ. Press Ltd. Dhaka. 364 pp.

Saifullah, A. S. M, M. H. Kabir, A. Khatun, S. Roy and M. S. Sheikh. 2012. Investigation of some water quality parameters of the Buriganga River. J. Env. Sci. Nat. Res. 5(2): 47-52.

Sarker, M, A. K. M. Rahman, J. B. Islam, K. S. Ahmed, M. N. Uddin and N. C. Bhoumik. 2015. Study of hydrochemistry and pollution status of the Buriganga River, Bangladesh. Bangladesh J. Sci. Ind. Res. 50(2): 123-134.

Welch, P. S. 1948. Limnological Methods. McGraw-Hill Book Co. Inc., New York. 381 pp.

Wetzel, R. G. and G. E. Likens. 2000. Limnological analysis. WB Saunders Co., Philadelphia. 357 pp.

Zerin, L., A. Gani and M. Khondker. 2017. Comparative water quality assessment of the river Buriganga near Dhaka Metropolis. Bangladesh J. Bot. 46(2): 589-598. 
